\title{
住民の関わり方・認識に着目した林地の共用構造のモデル に関する研究
}

Study on Formulation of Common use Structure Model for Woodlands in Rural Area

Based on Local Resident's Participation Level

\author{
太田 末来*, 小林 久** \\ Miki OTA, Hisashi KOBAYASHI \\ (*茨城大学大学院農学研究科, **茨城大学農学部) \\ ( ${ }^{*}$ Graduate School of Agriculture, IBARAKI Univ. ${ }^{* *}$ School of Agriculture, IBARAKI Univ.)
}

\section{I はじめに}

農村景観を形成する林地生 は は，近年様々な要 因によって, 減少, 荒廃しつつある。主な要因と しては, 管理当事者（林地所有者）に依存する管 理労㑃力の不足，相続税負担等が举げられる。

一方, 森林には景観保全, 自然に親しむ場の提 供などの生活㰃境保全, 自然㙅境保全などの機能 があるといわれているい。池辺らは所有者に関わ らず,その空間の持つ機能を地域住民が享受する」 共用化という観点から，このような機能をもつ森

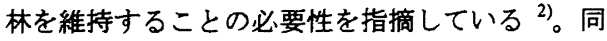
様に，内山は総有（私有でもあり共有でもある状 態）という概念を提示し，不特定多数の森林利用 は，規則と共同行動が必要であるとしている ${ }^{3)}$ 。 これらの研究は，林地 (森林) が地域资源として 適正に利用管理されるためには，共用资源として 位置つける必要があると指摘している。

では，モノの価值や機能が複数の個人に共通に 認知されることを，どのように捉えることができ るのだろうか。認知科学の分野では,「人間が作り 出したあらゆるもの（中略）が人間集団の共有す る埰境にそなわっていることが，観念の増殖を可 能にしている。(中略) 文化を説明することは特定 の観念がなぜ，いかにして感染するのかを説明す
ることである」吕というように，文化が社会に定着 することを説明するためには、観念の社会的な進 行プロセスを解くことの必要性が指摘されている。 また, Y.エングストロームは, 学習発達とは活 動が次第に社会的になっていくことであり，「活動 システムは，しだいに多くの人々に影翠を与える ようになっていくのである。(中略)さまざまな活 動システムとその中にいる人々が, より複雑なネ ットワーク（中略）を形成しながら，しだいに相 互依存的になっていくこと」と皇としいる。

本研究では，これらの観念队学習発達の考え方 を参考に，「不特定多数が，モラルを持って林地の 利用管理に接わり，林地の機能を享受すること」 を「共用」と定義し，林地の「共用」をどのように捉 えることができるかについて，モデル化を通して 考察する。

\section{II 研究の方法}

\section{1. モテル検討の前提}

Y.エンゲストロームは，人間活動を三角形棬造 のモデル（図 1）を用いて説明し，主体が対象に 傎きかけるためには，道具を用い，活動が共同体 によって集団的になされるようになると，そこに

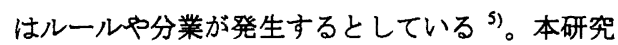


では，第一に，このモデルの主体，対象，共同体， 分業，ルールをそれぞれ林地所有者，林地，林地 非所有者注 ${ }^{2)}$, 非所有者が行う林地の利用管理作業, 林地利用管理時の規則と読み替え、これらを「要 素」と定義する。第二に，非所有者の他「要素」に 対する認識，意識などを「要素の関係性」として， モデルを検討する。「要素の関係性」は，図 2 のよ うに，(1)非所有者の林地所有者の認知，(2)林地と の関わり度合い，(3)林地利用管理時の規則の必要 性認識, (4)林地の利用管理内容の把握, (5)利用管 理活動への参加意欲として把握する。

今回の分析では，非所有者を対象にモデルを作 成しているため, 所有者と林地, 規則をつなぐ要 素の関係性」は考虑されていない。

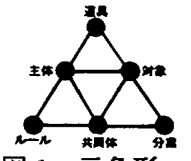

図 1 三角形 樥造モデ

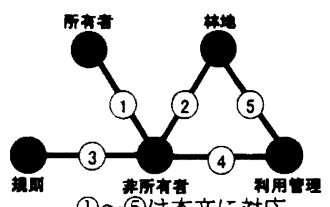

(1)〜(5)は本文に対応

図 2 「共用」權造のモデル

\section{2. 調査内容および対象地}

事前に行った林地所有者，地域住民および行政 担当者へのヒアリング結果を参考に，表 1 に示す 林地所有権の認識, 林地との関わり度合い（林地 への来訪頻度，未整備林地への立ち入り経験)，規 則の必要性に対する認識, 利用管理内容の把握

(10 項目), 利用管理活動人の参加意欲 (10 項目) を，(1)〜(5)の「要素の関係性」に対応する地域の林 地に関する質問項目として設定し，林地来訪者を 対象にアンケート調查を実施した。

調査対象地は，林地来訪者の特澌が異なると考 えられる埼玉県三富地域注 ${ }^{3)}$ と, 茨城県牛久地域 を選定した。

三富地域は，江戸時代に屋数，畑地，林地から なる短冊状地割の新田開発が行われた畑作農業地 帯 ${ }^{6)}$ で，落ち莱堆肥の供給源であった林地が現在 でも広く残存する地域である。近年は，林地への 不法投棄問題などを契機に林地保全への動きが活 発化し, 行政, JA, 林地所有者, 地域住民の協力 による先駆的な管理活動が行われている。

牛久地域は，明治時代以降に開拓が行われ，薪
表 1 アンケート項目

\begin{tabular}{|c|c|c|c|c|c|c|}
\hline \multirow{2}{*}{ 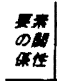 } & フンクート积目 & \multicolumn{5}{|c|}{ 回䇺 } \\
\hline & 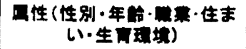 & \multicolumn{5}{|c|}{ 択一式 } \\
\hline (1) & $\begin{array}{l}\text { 林地のほとんどが、㑭人所市 } \\
\text { であることを知っているか }\end{array}$ & 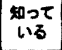 & $\begin{array}{c}\text { 如 } 5 \text { t } \\
6\end{array}$ & & & \\
\hline \multirow{2}{*}{ (2) } & どれくらいの責及で来るか & $\begin{array}{l}\text { 洞に } \\
\text { 回以上 } \\
\end{array}$ & 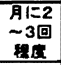 & $\begin{array}{l}\text { 月に }=1 \\
\text { 回相度 }\end{array}$ & $\begin{array}{l}\text { 年1二数 } \\
\text { 回租温 }\end{array}$ & 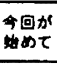 \\
\hline & $\begin{array}{l}\text { 未贯伹の林地に立ち入ったこ } \\
\text { とがあるか }\end{array}$ & ある & ない & & & \\
\hline (3) & 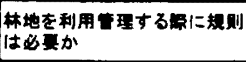 & 敞䇃に & 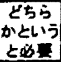 & $\begin{array}{c}\text { どちら } \\
\hbar \omega \bar{\lambda} \\
\text { ない }\end{array}$ & 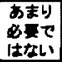 & 恶原 \\
\hline (4) & 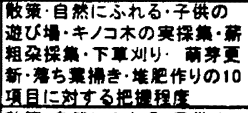 & $\begin{array}{l}\text { 人に样 } \\
\text { L<充 } \\
\text { られる }\end{array}$ & $\begin{array}{l}\text { よ<知つ } \\
\text { ている }\end{array}$ & 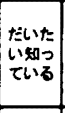 & $\begin{array}{c}\text { かまり } \\
\text { よくわ } \\
\text { からな } \\
\text { い }\end{array}$ & $\begin{array}{c}\text { 全くわ } \\
\text { からな } \\
\text { い }\end{array}$ \\
\hline (5) & 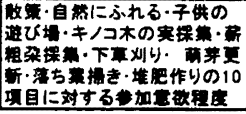 & $\begin{array}{l}\qquad \text { 加し } \\
\text { t=こと } \\
\text { がある }\end{array}$ & 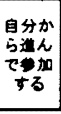 & 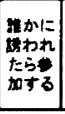 & $\begin{array}{l}\text { 只䗲は } \\
\text { あるけ } \\
\text { どわか } \\
\text { らない }\end{array}$ & $\begin{array}{l}\$ m L \\
な い\end{array}$ \\
\hline
\end{tabular}

炭林や入会地として利用された林地が近年まで広 く残された地域である 7)。藉炭林等の利用が衰退 するとともに，管理が不十分となり，現在では荒 廃の進んだ林地が少なくない。しかし一方で，林 地利用管理活動を行う市民団体が增加する傾向が あり，地域住民による林地保全への気運が高まり つつある地域といえる。

三富地域では, 2003 年 12 月 13 日，2004 年 2 月 14 日に狭山市の赤坂の森公園, およびその周辺 私有林地におけるイベント・作業来訪者を対象に， また牛久地域では，2004 年 1 月 10，11 日に牛久 市自然锶察の森への来訪者を対象に，澌問表を手 渡しで配布・回収する方法で害施した。

\section{3. 解析の手順}

第一に, アンケート結果に基づいて、回答者 (サ ンプル) のクラスター分析を行い、グループ分け を行う。第二にグループの特徴を説明し、最後に モデルを用いて各グループの図的表現を試みる。

\section{III アンケート結果}

両地域でのアンケート結果は, 表 2 の通りで, 有効回答数は，三富地域で 114，牛久地域で 143 であった。回答者の楼成は，性別，年齡において， 両地域に差は認められなかった（表 3)。県外から の来訪者は牛久地域では $8 \%$,三富地域では $1 \%$ で 


\begin{tabular}{|c|c|c|c|c|}
\hline & 是布毁 & 回集好 & 回収 $(\%)$ & 有朝回管 \\
\hline E7 & 140 & 118 & 75 & $114(34)$ \\
\hline $4 \lambda$ & 149 & 146 & 98 & $143(7)$ \\
\hline
\end{tabular}

\begin{tabular}{|c|c|c|c|c|c|c|c|c|}
\hline & & & 表 3 & \multicolumn{3}{|c|}{ 回答者の虽性 } & \multicolumn{2}{|c|}{ (単位：\%) } \\
\hline & & 女 & $10 \mathrm{ft}$ & $20 \mathrm{H}$ & $30 \mathrm{At}$ & $40 \mathrm{ft}$ & $50 \mathrm{tt}$ & $60 \mathrm{ft}$ \\
\hline$\equiv 7$ & 61 & 39 & 4 & 11 & 18 & 25 & 21 & 21 \\
\hline $4 x$ & 64 & 36 & 1 & 6 & 22 & 14 & 28 & 29 \\
\hline
\end{tabular}

あった。なお，回答には林地所有者が含まれ，そ の全回答に対する割合は，三富地域で $30 \%$ ，牛久 地域で $5 \%$ であった。

両地域の結果を比較すると図 3 に示すように, 下草刚りに関して, 三富地域で“参加したことがあ る”、“誰かに誘われたら参加する”とする回答割合 が，牛久地域では“興味があるがわからない”、“参 加しない”とする回答割合が高い。この傾向は，他 の管理に関する活動(薪・そだ採集, 間伐·枝打ち, 萌芽更新，落ち葉掃き，堆肥作り)でも同様であ る。

一方，散策に対する参加意欲には両地域で大き な差は見られない。この傾向は他の利用に関する 活動（自然にふれる，子供の遊び場，木の実・キ， コ採集)でも同様である。

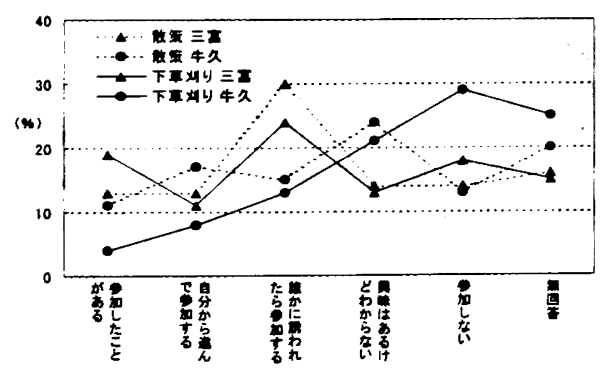

図 3 地域別活動参加意欲の程度割合

\section{IV「共用」のモデル化}

\section{1. サンプルの分類}

「要素の関倸性」に対応する啠問項目 (24 項目) を変数として, 三富地域, 牛久地域それぞれの回 答についてウォード法によるクラスター分析を行 う。分析には, 林地所有者の回答を除く有効回答 を用いた（三富：80サンプル，牛久：136サンプ

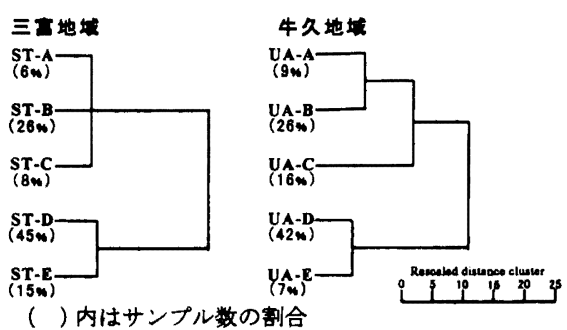

図 4 分類結果

ル)。分析結果は図 4 のようになり，両地域ともに 2 群，5グループに分類することができる住4。

この分析結果から, 各グループの特性を把握,

整理するために，5段階の回答が得られる質問項 目については, $-1,-0.5,0,0.5,1,2$ 段階の回答 が得られる澌問項目については, -1，1のように, 頻度, 認識などが高いものほど值が大きくなるよ うに各サンプルの回答結果を-1〜1 範囲の值に調 整して, 各グループの平均值, 0.5 以上の回答率 (0.5 以上回答率)および無回答率を求める(表 4$)$ 。 表 4 は分類された各グループが各「要素の関係 性」に対して,どのように反応するかを示している といえる。

\section{2. グループの特街}

表 4 を用いて, 三富地域および牛久地域の各グ ループの特徵を解釈すると次のようにまとめるこ とができる。

(1) 三富地城

ST-A（低関心グループ）: 所有権認識 (-0.6:グル 一プの平均値, 以下同様), 来訪頻度 (-0.9), 未 整備林地への立ち入り経酸 (-0.6) の平均値がマ イナスで，規則の必要性 (0.3) は分類された 5 ク ループ中最も低い。また，活動内容の把暒はすべ て無回答，活動参加意欲は散策 $(-0.1)$ 以外無回 答である。これらの特徽から，所有権の認識，林 地との関わり, 利用管理に対する認識, 参加意欲 が最も希薄なグループと考えられる。

ST-B (低㑇傤・低意欲グループ) : 所有権認識 $(-0.4)$ ， 来訪頻度 $(-0.8)$, 未整備林地への立ち入り経験 (0.0)の平均值は低いが, 規則の必要性 (0.7) に 対する認識は高い。活動内容の把挃（-0.9〜-0.4） および活動参加意欲 $(-0.8 〜-0.2)$ はいずれもマイ 
表 4 各グループの平均値, 0.5 以上回答率, 無回答审

\begin{tabular}{|c|c|c|c|c|c|c|c|c|c|c|c|c|c|c|c|c|c|c|c|c|c|}
\hline & & & & & & & & & & & & & & & & & & & & & \\
\hline & Fin & -0.6 & & -0.4 & 28 & 0.7 & & 0.1 & $\frac{56}{8}$ & 0.8 & & 0.2 & & -0.4 & & -0.5 & & -0.2 & & 1.0 & \\
\hline & and & -0.9 & & -0.8 & & -0.4 & & -0.8 & 3 & 0.3 & & 0.0 & & -0.1 & & 0.0 & & -0.3 & & 0.8 & \\
\hline & म210 & -0.6 & & 0.0 & $\frac{48}{8}$ & 0.3 & ह7) & -0.1 & 47 & 1.0 & 10 & -0.2 & & -0.2 & & 0.5 & & 0.2 & & 0.8 & \\
\hline & $\operatorname{mon} \cos$ & 0.3 & $\frac{40}{40}$ & 0.7 & $\frac{86}{8}$ & 0.4 & 50 & 0.7 & $\frac{86}{8}$ & 0.8 & 8 & 0.6 & & 0.7 & & 1.0 & 8 & 0.7 & 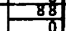 & 0.7 & 8 \\
\hline & 0 & & $\frac{0}{100}$ & -0.5 & $\frac{14}{0}$ & 0.1 & 3 & -0.1 & $\frac{19}{3}$ & 0.4 & & $\overline{0.5}$ & $\frac{8}{92}-1-2-1$ & -0.3 & & 0.3 & 4 & -0.2 & & 0.3 & 4 \\
\hline & $01=\sin 6$ & & $\frac{0}{100}$ & -0.5 & 1 & 0.1 & 33 & 0.0 & 28 & 0.3 & 4 & 5 & & -0.2 & & 0.3 & 4 & -0.1 & $\underline{2}$ & 0.2 & 4 \\
\hline & $7 \omega \infty=0$ & & $\frac{0}{00}$ & -0.4 & $\frac{14}{0}$ & 0.2 & 3.3 & -0.1 & 19 & 0.0 & & & & -0.4 & & 0.3 & 4 & -0.2 & 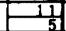 & -0.1 & 1 \\
\hline & *の & & 8 & -0.8 & & -0.1 & $\frac{1}{1}$ & -0.3 & 11 & -0.2 & & & & -0.8 & & -0.1 & 2 & -0.3 & 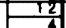 & -0.4 & \\
\hline & 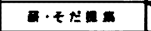 & & $\frac{10}{100}$ & -0.8 & & -0.1 & $\frac{11}{17}$ & -0.2 & $\frac{14}{0}$ & 0.1 & & & & -0.9 & & -0.1 & 3 & -0.5 & 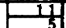 & 0.1 & 5 \\
\hline & 4.203 & & 100 & -0.9 & & -0.3 & $\frac{17}{8}$ & -0.4 & $\frac{11}{3}$ & 0.4 & & & 100 & -0.9 & & 0.2 & 5 & -0.3 & 18 & 0.4 & 6 \\
\hline & $T=x y$ & & $\frac{0}{100}$ & -0.8 & & -0.2 & 17 & -0.3 & 14 & 0.6 & & & 80 & -0.8 & & 0.3 & 5. & -0.3 & 74 & 0.5 & 78 \\
\hline & 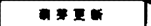 & & 9 & -0.8 & & -0.2 & 33 & -0.4 & $\frac{8}{3}$ & 0.5 & & & 80 & -0.9 & & 0.2 & $\frac{45}{14}$ & -0.6 & 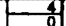 & 0.1 & 5 \\
\hline & n5met & & $\frac{8}{100}$ & -0.7 & & 0.2 & 50 & 0.0 & $\frac{33}{0}$ & 0.5 & & & $\frac{9}{100}$ & -0.8 & & 0.3 & $\frac{64}{9}$ & -0.2 & $\frac{14}{2}$ & 0.5 & 7 \\
\hline & $x=n y$ & & $\frac{0}{100}$ & -0.9 & - & 0.2 & $\frac{17}{0}$ & -0.1 & 17 & 0.5 & & & 10 & -0.8 & & 0.3 & $\frac{75}{0}$ & -0.3 & If & 0.3 & $\frac{87}{0}$ \\
\hline & (1) & -1.0 & $\frac{8}{80}$ & -0.4 & $\frac{18}{8}$ & 0.0 & $\frac{8}{83}$ & 0.3 & 42 & 0.1 & 3. & & 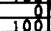 & -0.3 & 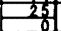 & -0.6 & $\frac{7}{68}$ & 0.0 & 39 & 0.6 & 89 \\
\hline & $\ln x=\sin \delta$ & & 100 & -0.2 & 28 & & $\frac{9}{100}$ & 0.3 & 53 & 0.7 & $\frac{87}{17}$ & .0 & 92 & -0.3 & & -0.9 & 82 & 0.1 & $\frac{40}{4}$ & 0.6 & $\frac{89}{0}$ \\
\hline & $\mp * \infty \geqslant 0 *$ & & 100 & -0.4 & 24 & & की & 0.2 & -44 & 0.2 & 4 & & 10क्ष & -0.4 & 2 & -1.0 & 8 की & -0.2 & 24 & -0.2 & $\frac{33}{31}$ \\
\hline & 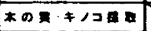 & & 100 & -0.5 & 10 & -0.5 & की & 0.1 & $-5 \frac{3}{0}$ & 0.0 & & & $\frac{100}{100}+(-2)$ & -0.5 & 1 & -1.0 & 86 & -0.2 & 19 & 0.3 & $\frac{44}{0}$ \\
\hline & - & & 100 & -0.6 & & & 100 & -0.2 & 17 & 0.8 & $\frac{83}{0}$ & & $\frac{0}{100}$ & -0.7 & & -1.0 & $\frac{80}{86}$ & -0.4 & 9 & 0.2 & $\frac{44}{0}$ \\
\hline & $M 2 \cdot 8 \pi 5$ & & 108 & -0.7 & & & 100 & -0.1 & $\frac{14}{6}$ & 0.8 & $\frac{83}{8}$ & & $\frac{100}{100}$ & -0.9 & $\exists$ & -1.0 & 86 & -0.3 & 11 & 0.8 & $\frac{100}{0}$ \\
\hline & F*40 & & 100 & -0.7 & $\frac{0}{5}$ & & $\frac{0}{100}$ & -0.1 & 22 & 1.0 & $\frac{100}{0}$ & & $\frac{50}{100}$ & -0.8 & 3 & -1.0 & $\frac{9}{86}$ & -0.3 & -12 & 0.8 & 100 \\
\hline & 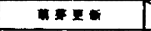 & & 100 & -0.8 & $\frac{0}{5}$ & $\gamma$ & 100 & -0.1 & $\frac{14}{6}$ & 0.8 & -75 & & $\frac{10}{100}$ & -0.9 & 9 & -1.0 & 86 & -0.4 & $-\frac{5}{2}$ & 0.4 & $\frac{6}{1}$ \\
\hline & n502 & & $\frac{10}{100}$ & -0.5 & 10 & 0.7 & $\frac{33}{50}$ & 0.2 & 39 & 1.0 & 100 & & 10 & -0.9 & $\frac{9}{14}$ & -1.0 & $\frac{10}{86}$ & -0.3 & 79 & 0.9 & 10 \\
\hline & un $n$ & & 108 & -0.8 & -5 & 0.0 & $\frac{0}{83}$ & 0.1 & 3y & 0.6 & & & 10 & -0.8 & 0 & -1.0 & 86 & -0.3 & 12 & 0.8 & 78 \\
\hline & 绵音 & & & & & & & & & & & & & & & & & & 0.5 & & $\frac{196)}{36)}$ \\
\hline
\end{tabular}

ナスとなる。これより, ST-A グループと同様に所 有権の認識, 林地との関わり，利用管理に対する 認識，参加意欲が高くないグループといえる。

ST-C（低意欲グループ）：規則の必要性（0.4）は ST-B グループに比べて低いが, 所有権認識 (0.7), 末整備林地への立ち入り経験（0.3）はプラスとな る。また来訪頻度 $(-0.4)$ および活動内容の把握 $(-0.3 \sim 0.2)$ はST-A, ST-B, ST-D グループより 高い値となるが, 活動参加意欲に対しては無回答 が多い。このような特徽から, 所有権認識, 林地 との関わり、利用管理に対する認識はあるが, 活 動参加意欲はほとんど認められないグループとい える。

ST-D（低利用・有意欲グループ）:来訪頻度 $(-0.8)$, 末整備林地への立ち入り経舾（-0.1）はマイナス となるが, 所有権認識 (0.1), 規則の必要性に対 する認識 (0.7) は高い。活功内容の把握は自然に ふれる $(0.0)$, 落ち莱掃き (0.0) 以外はマイナス となるが，活動参加意欲は薪・そだ採集 $(-0.2)$, 間伐·枝打ち $(-0.1)$, 下草刚り $(-0.1)$, 萌芽更新 $(-0.1)$ を除いて $0.1 \sim 0.3$ とプラスになる。し
たがって, 所有権の認識, 利用管理に対する認識, 活動参加意欲はあるが, 林地との関わりは低いグ ループと考えられる。

ST-E（高認諳・高意欲グループ）：所有権の認識 $(0.8)$ ，来訪頻度 $(0.3)$ ，末整備林地人の立ち入り 経験 (1.0)，規則の必要性（0.8）はいずれもプラ スで，活動内容の把㩧は木の実・キノコ採集 $(-0.2)$ を除いて 0.0〜0.6とプラスである。活動参加意欲 (0.0〜1.0) はすべてプラスで, 分類されたグルー プの中で最も高い值となる。このような特徽から， 所有権の認識, 林地との関わり，利用管理に対す る認識, 活動参加意欲が最も高いグループといえ る。

（2）牛久地城

UA-A（低関心グループ）: 所有権認識（0.2）, 来 訪頻度（0.0）はプラスだが，末整備林地への立ち 入り経験 (-0.2) がマイナスで, 規則の必要性 (0.6) は 5 グループ中で最も低い。また，活栜内容の把 握, 活動参加意欲は, ほとんどが無回答である。 したがって， ST-A と同様の特徴がみられるグル 一プといえる。 
UA-B（低認識・低意欲グループ）：所有権認識 $(-0.4)$, 来訪頻度 $(-0.1)$, 未整備林地人の立ち入 り経検 (-0.2) はマイナスで, 規則の必要性 (0.7) に対する認識は高い。活的内容の把握 (-0.9〜-0.2) はマイナス, 活物参加意欲 (-0.9〜-0.3) もマイナ スとなり，ST-B と同様の特街がみられるグルーフ といえる。

UA-C（低意欲グループ）：来訪頻度 $(0.0)$ ，末整 備林地への立ち入り経験（0.5）はプラス，規則の 必要性（1.0）は最も高い值になるが，所有権認識 （-0.5）はマイナスになる。活助内容の把握は, 木の実·キノコ採集 (-0.1)，薪·そだ採集 (-0.1) 以外はプラスとなり，0.5 以上回答率も $23 \sim 64 \%$ と高いが，活動参加意欲に対しては無回答が半数 を占める。したがって, 所有権認識を除いて ST-C と同様の特徽がみられるグループと考えられる。

UA-D（低利用・有意欲グループ）：所有権認識

(-0.2) はマイナスで, 来訪頻度 (-0.3) は 5 グル 一プ中最も低いが，末整備林地への立ち入り経験

(0.2)，規則の必要性に対する認識（0.7）はプラ スとなる。活動内容の把握（-0.6〜-0.1）はマイナ スとなり, 活動参加意欲は, 散策 $(0.0)$ ，自然に ふれる（0.1）以外はマイナスとなるが，UA-A, UA-B, UA-C よりは高い值となる。したがって, ST-D と同様の特徴がみられるグループといえる。 UA-E（高認㵝・高意欲グループ）：所有権の認識 (1.0), 来訪䅡度 (0.8), 未整備林地人の立ち入り 経験 (0.8), 規則の必要性（0.7）はいずれもプラ スで, 活動内容の把握は散策および子供の遊び場 (-0.1)，木の実・キノコ採集 (-0.4) を除いて 0.1 〜 0.5 とプラスである。活轨参加意欲は，子供の遊 び場（-0.2）を除いて 0.2 0.9 で最も高い值とな り, 0.5 以上回答率も高い。これらの特街から, ST-E に類似したグループといえる。

（3）グループ間の比鉸

このように，三富地域，牛久地域において，特 街が類似するグループを識別することができた。

「不特定多数が，モラルを持って林地の利用管理 に㩲わり，林地の機能を享受すること」という本研 究における林地の「共用」の定義に従うと, 分類さ れたグループのうち, 高認識·高意欲グループが, 最も「共用」の進んだ段階にあると考えられる。
また,クラスター分析結果から，分類された 5 グループは両地域ともに低関心グループ, 低認識・ 低意欲グループ，低意欲グループと，低利用・有意 欲グループ, 高認識・高意欲グループの 2 群に分け られる。前者の群に属すグループと後者の群に属 すグループを比較すると，利用管理活動への参加 意欲が前者で低く，後者で高いという点に，大き な相違を認めることができる。

さらに, 後者の群に属す低利用·有意欲グループ と高認識・高意欲グループを比較すると，䔉・そだ 採集，間伐·枝打ち，下草刚り，萌芽更新，落ち莱 掃き，堆肥作りの林地管理に関する活动への参加 意欲が, 低利用・有意欲グループで低い傾向がある。

このようなグループ間の特徽の遠いを参考にす ると，利用管理活胹への参加意欲が，「共用」にお いて重要な要因になり得ること，その中でも特に 管理活動への参加意欲が「共用」の重要な規定要因 になり得ると考えられる。

3.「共用」椣造のモデルによる表現

各質問項目の平均值を参考に「要素の関係性」の 強弱を段階分けすることで，図 2 に示す「共用」構 造のモデルを用いて，両調査対象地における各グ ループの図的表現を試みる。段階は，算出した各 グループの平均值を 0.5 以上, 0 以上 0.5 末満, -0.5 以上 0 末満， -0.5 末満の 4 段階に設定する。

(1)非所有者の林地所有者の認知, (3)林地利用管 理時の規則の必要性認識の「要素の関係性」につい ては，設定した質問がそれぞれ 1 項目なので，対 応する項目の平均値を用いる。

(2)林地との関わり度合いに該当する兵問項目は， 来訪頻度と末整備林地への立ち入り経監がある。 各グループで, 両者の平均值は異なっているが， グループ間の変動パターンは類似しているので, ここでは, 両者の平均値を求め 4 段階に区分する。

(4)林地の利用管理内容の把提は, 10 質問項目が 該当する。グループ間の平均値の変動パターンが 類似しているので, 全 10 項目の平均值をグループ ごとに求め，これを用いる。ただし，無回答率の 高いグループが存在することから，無回答率の平 均值が $80 \%$ 以上のものは， -0.5 末満として扱う。

(5)利用管理活動への参加意欲は，10 項目が該当 
する。低関心グループ, 低認識·低意欲グループ, 低意欲グループ間の各項目の平均値変動は類似す るが，低利用・有意欲グループ，高認識・高意欲グ ループ間で変動の異なる斦問項目が認められる。 全体的に，低利用・有意欲グループ，高認識・高意 欲グループ間の平均値差は，利用に関する活動で 小さく，管理に関する活助で大きい傾向がある。 そこでここでは, 低利用・有意欲グループ, 高認識・ 高意欲グループをより明瞭に区分する澌問項目と して，管理に関する活動に相当する項目の平均值 を求め,これを用いる。また，(4)と同様に無回答 率の平均値が $80 \%$ 以上のものは, -0.5 未満として 扱う。

以上の手順で「要秦の関係性」を，各グループ について表現すると，図5のようになる。

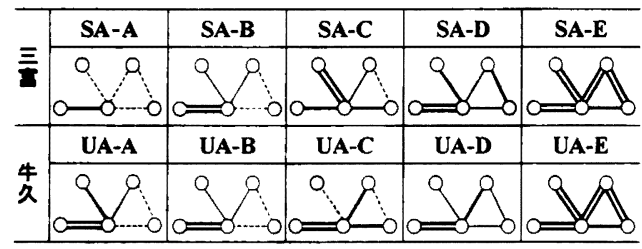

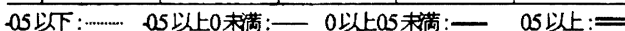
図 5 グループのモデル構造

\section{V おわりに}

本研究では，林地非所有者に対するアンケート 結果を分析することで，林地の「共用」を説明する モデルを考察した。考察にあたって第一に，林地 所有者, 林地, 非所有者, 林地利用管理時の規則, 非所有者が行う林地の利用管理活功の「要素」およ び，林地所有者の認知，林地との関わり度合い， 林地利用管理時の規則の必要性認識，林地の利用 管理内容の把握, 利用管理活動への参加意欲の「要 素の関倸性」からなる林地の「共用」構造のモデル を提示した。第二に, アンケートの回答を分類し， 各グループの特徵を把握することでモデルの有効 性を示すと共に，「共用」を説明するためにモデル の「要素の関係性」を把握することが有用であるこ
とを明らかにした。また，グループ間の比較を通 して「共用」が進行するためには，林地管理に関す る活功への参加意欲が重要であることを推察した。 ただし，本研究で提示したモデルは非所有者に 着目して検討されたものであるため，所有者側か らの視点を加える必要がある点において課題を残 している。また，用いた質問項目には，重複的な もの，適正な回答が得られなかったものがあった ことから，より適切に「要素の関倸性」を把暒する ことのできる項目の設定が必要である点において も，改善が必要と考えられる。さらに，今回は非 所有者を核に平面的なモデルを提示したが，林地 を公的な場所として認樴する例も見られたことか ら，規則と林地との関係性を表現するような立体 的なモテルも考えられるため，モデル自体の再検 討が求められる可能性もある。

したがって，より汎用的なモデルとして「共用」 の段階評価や地域間比較を行うためには，「関倸 性」を示す適切な項目の設定と共に, 他地域での分 析，考察を通して，ここで示したモデルの枠組み を検討し，さらに拡張·改良することが望まれる。

$$
\text { <注㹞> }
$$

注 1）里山，平地林と呼ばれる二次林のことを指す。

注 2) 本来俚, 林地非所有の地域住民が共同体に相当する ものと考えられるが，本研究では林地来貾者を調查 対象としている。

注 3）兰畐地域は現在の埼玉県川越市，所沢市，狭山市， 大井町，三芳町に位孟する。

注 4）分析対象のサンプルが最も離れている距離を 25 と し，それぞれの距離は相対的に表される。本研究で は両地域とも5のところで 5 分類している。 <考文嗝〉

1)夆柳みどり・内藤正明(1989):「森林の持つ生活境保全 機能の評価に閶する研究一住民評価指滕にもとつく評 価指楼の作成一」留村計画学, Vol.8,No.2, pp22-34.

2)池辺このみ・田畑貝专(1983): [居住環境における緑被空 間憡造とその共用化について」造園雜誌 46(5),pp229－ 233.

3)内山䇻(2001):『森の列岛に基らす〜森林ボランティアか らの政策提言〜』,コモンズ.

4)ダン・スペルベル 苦野盾樹訳(2001):『表像は感染するー 文化への自然主咅的アプローチー』,新曝社.

5)ユーリア・エンゲストローム山住勝広他訳(1999):『拡張 による学習』,新曤社。

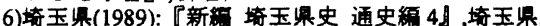

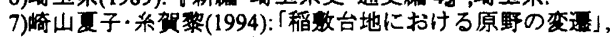
筑波棵境研究,第 15 奇,pp24-44.

"Common use modeling" in rural woodlands was examined based on the questionnaire survey to visitors to the woodlands in both Santome and Ushiku Areas. Framework of model was prepared referring existing conception of human activities model in Developmental Psychology. Then, the questions that were considered to describe the model were set for the questionnaire survey. Based upon the survey results, a model was formulated for two target areas, by local residents, wood owners, woodland use/management, rule as an "element" and "relation between elements" which were express at the level of recognition, understanding and participation to woodland use/management. 